BISMA - Bisnis dan Manajemen -Volume 9 No. 1 Oktober 2016

\title{
PENGARUH LIKUIDITAS DAN KUALITAS ASET TERHADAP PROFITABILITAS PADA BANK UMUM NASIONAL(STUDI PADA BURSA EFEK INDONESIA PERIODE 2010-2014)
}

\author{
Daniel Siahaan, Nadia Asandimitra \\ Fakultas Ekonomi Universitas Negeri Surabaya \\ Danielsiahaan93@gmail.com
}

\begin{abstract}
This study exmines the factors that affect the profitability of the national commercial banks. This study used data 32 commercial banks that go pulic in Indoesia Stock Exchange period 2010-2014. Sampling was done by purposive sampling method. This study used multiple linear regression analysis using SPSS 20. Independent variable of this study is Liquidity (LDR) and Asset Quality (NPL). The results of the study explain that Liquidity is a positive effects on Profitability. Liquidity be a measure of the success a bank to obtain high profitability. The lower the LDR reflects the bank has not been able to optimize third-party funds (DPK), which will be distributed to customers as a credit. Asset Quality negatively affect Profitability. High-Quality assets in a bank means more credit problems experienced by banks and will result in losses in the bank.
\end{abstract}

Keywords: Profitability, Liquidity, and Asset Quality.

\section{PENDAHULUAN}

Sektor perbankan dalam perekonomian suatu negara memilikki peranan yang sangat penting dalam kehidupan masyarakan saat ini yang sebagian besar melibatkan jasa dari sektor perbankan. Berdasarkan UU RI No. 10 tahun 1998, tanggal 10 November 1998 yang menjelaskan mengenai perbankan,bahwa Bank adalah badan usaha yang menghimpun dana dari masyarakat dalam bentuk kredit atau bentuk lainnya dalam rangka meningkatkan taraf hidup masyarakat Bank.

Bank berperan sebagai lembaga penghubung (intermediasi) antara masyarakat surplus dengan masyarakat defisit. Jadi masyarakat yang berlebihan dana dapat menyimpannya di bank untuk selanjutnya disalurkan oleh bank ke masyarakat yang membutuhkan dana. Kondisi kesejahteraan ekonomi dalam suatu negara pun tergantung pada kemampuan bank dalam mengelola dana dari masyarakat untuk disalurkan kembali pada pihak-pihak yang membutuhkan dana.

Ketidakmampuan bank dalam memenuhi permintaan kredit dan membayar simpanan yang ditarik kembali oleh nasabah akan menggoyahkan kepercayaan nasabah terhadap kualitas bank tersebut. Pengelolaan bank mempunyai dua tujuan yaitu tujuan jangka panjang dan tujuan jangka pendek.Tujuan jangka panjang suatu bank adalah mencari keuntungan atau laba, sedangkan tujuan jangka pendek suatu bank adalah memenuhi cadangan minimum, pelayanan yang baik kepada langganan dan strategi dalam melakukan investasi (Nopirin, 1992:23). Dalam membangun perekonomian Negara, perbankan Nasional berperan sangat penting dan diharapkan berperan aktif dalam kegiatan pembangunan nasional maupun regional.

Dengan demikian, pelaku ekonomi yang membutuhkan dana untuk menunjang kegiatan atau kebutuhannya dapat terpenuhi sehingga roda perekonomian dapat bergerak. Oleh karena itu, kesehatan suatu Bank sangat dibutuhkan. Tingkat kesehatan dapat dilihat berdasarkan besar profitabilitas bank tersebut. Pengukuran kondisi kesehatan suatu bank dapat diukur dengan rasio-rasio keuangan yang meliputi aspek permodalan, aspek asset, aspek manajemen, aspek rentabilitas, aspek likuiditas, dan aspek sensitivitas. Metode atau cara penilaian kinerja keuangan bank seperti ini biasa disebut dengan CAMELS (Capital, Asset, Management, Earning, Liquidity, Sensitivity to Market).

Metode tersebut sesuai dengan Peraturan Bank Indonesia Nomor 6/23/DPNP tanggal 31 Mei 2004 tentang Sistem Penilaian Tingkat Kesehatan Bank Umum. Penilaian terhadap laba atau earning dapat dilakukan dengan menggunakan analisis profitabilitas, di mana rasio profitabilitas yang penting bagi bank adalah Return On Asset (ROA). ROA penting bagi bank karena digunakan untuk mengukur efektivitas perusahaan dalam menghasilkan keuntungan dengan memanfaatkan aktiva yang dimilikinya. Semakin besar ROA akan menunjukkan kinerja perusahaan semakin baik, karena tingkat pengembalian (return) semakin besar.

Indikator yang pertama adalah likuiditas. Likuiditas merupakan suatu proses pengendalian dari alat-alat likuid yang mudah ditunaikan guna memenuhi kewajiban bank yang harus segera dibayar sesuai hari jatuh tempo. Dalam hal ini rasio likuiditas yang digunakan adalah Loan to 


\section{Daniel Siahaan dan Nadia Asandimitra-Pengaruh Likuiditas Dan Kualitas Aset...}

Deposit Ratio (LDR).Dalam penelitian Putri (2008), Indikator utama untuk mengukur kemampuan sebuah bank dalam menyalurkan kredit adalah Loan to Deposit Ratio (LDR).

Rasio LDR digunakan untuk mengukur kemampuan Bank tersebut untuk membayar hutang-hutangnya dan membayar kembali,serta dapat memenuhi permintaan kredit yang diajukan. adalah rasio antara seluruh jumlah kredit yang diberikan terhadap dana pihak ketiga.Besarnya jumlah kredit yang diberikan akan menentukan keuntungan Bank. Jika Bank tidak mampu menyalurkan kredit sementara dana yang terhimpun banyak, maka akan menyebabkan Bank tersebut mengalami kerugian (Kasmir, 2004). Indikator yang kedua adalah kualitas asset. Kualitas aset adalah adalah perbandingan antara classified (kredit kurang lancar, kredit diragukan, kredit macet) dengan total kredit yang diberikan. Dalam hal ini rasio kualitas aset yang digunakan adalah Net Performing Loan (NPL).Rasio NPL digunakan untuk mengukur kemampuan manajemen Bank dalam mengelolah kredit bernasalah yang diberikan oleh Bank.

Risiko kredit yang diterima oleh Bank merupakan salah satu risiko usaha Bank yang diakibatkan dari ketidakpastian dalam pengembaliannya atau yang diakibatkan dari tidak dilunasinya kembali kredit yang diberikan oleh pihak Bank kepada pihak debitur. Semakin tinggi rasio ini maka akan semakin buruk kualitas kredit Bank yang menyebabkan jumlah kredit bermasalah semakin besar dan menyebabkan kerugian,sebaliknya bila semakin rendahya NPL maka laba atau profitabilitas Bank tersebut akan semakin meningkat.

Beberapa penelitian terdahulu juga menunjukkan hasil yang tidak konsisten, maka dari itu hal tersebut dapat mendorong saya untuk melakukan penelitian ini. Menurut penelitian yang dilakukan oleh Puspitasari (2009) dan Rosdiana (2010) bahwa variabel LDR berpengaruh positif signifikan terhadap ROA, alasannya karena semakin tinggi LDR menunjukkan semakin tinggi dana yang disalurkan dan semakin rendah LDR menunjukkan kurangnya efektifitas bank dalam menyalurkan kreditnya. Sedangkan variabel NPL berpengaruh negatif terhadap ROA. Alasannya karena semakin kecil NPL semakin kecil pula risiko kredit yang ditanggung oleh pihak bank, dengan kata lain semakin tinggi NPL akan menurunkan profitabilitas bank.

Tetapi pada penelitian Manrov (2009) menyatakan bahwa variabel LDR berpengaruh negatif terhadap ROA, dan menurut Prasnanugraha (2007) menyatakan bahwa variabel LDR tidak berpengaruh terhadap ROA. Dan juga menurut penelitian Prasnanugraha (2007) menyatakan bahwa variabel NPL berpengaruh positif terhadap ROA, Ahmad (2009) yang menyatakan bahwa variabel NPL tidak berpengaruh terhadap ROA. Berdasarkan uraian di atas, maka judul yang dapat dikemukakan dalam penelitian ini adalah "Pengaruh Likuiditas dan Kualitas Aset terhadap Profitabilitas pada Bank Umum Nasional (Studi pada Bursa Efek Indonesia Periode 2010-2014)".

\section{KAJIAN PUSTAKA}

1. Manajemen Likuiditas

A. Commercial Loan Theory

Likuiditas bank menurut teori ini akan dapat terjamin apabila aktiva produktif bank terdiri dari kredit jangka pendek yang dicairkan dalam kegiatan usaha yang berjalan secara normal. Dan apabila bank yang bersangkutan akan memberikan kredit yang lebih panjang hendaknya sumber dana diambil dari modal bank dan sumber dana jangka panjang. Secara khusus teori ini menyatakan bahwa bank harus hanya memberikan kredit jangka pendek atau selfliquiditing loans.Misalnya kredit yang digunakan untuk modal kerja. (Veitzhal, 2007: 387).

Kelemahan commercial loan theory ini menurut Veitzhal (2007: 387) adalah:

1. Banyak kredit bukan jangka pendek dan tidak selfliquidating.

2. Dalam situasi ekonomi yang sedang lesu, kredit modal kerja yang pelunasannya berasal dari arus kas nasabah debitur akan menjadi tidak lancar.

3. Kredit jangka pendek dapat menjadi jangka panjang melalui perpanjangan waktu secara terus menerus.

4. Dalam perekonomian yang semakin maju, kredit jangka menengah/panjang akan menjadi semakin penting dan dibutuhkan.

5. Teori ini mengabaikan kenyataan bahwa dalam keadaan normal atau stabil, sumber-sumber dana bank seperti giro, tabungan, dan deposito memungkinkan untuk disalurkan sebagai kredit yang jangka waktunya lebih panjang.

6. Secara implisit, teori ini menganggap bahwa likuiditas dapat terpenuhi dengan hanya mengandalkan sumber dari pelunasan dan atau pembayaran kredit oleh nasabah. Padahal, penarikan simpanan dan pencairan kredit dapat melebihi likuiditas yang hanya bersumber dari pelunasan kredit.

B. Shiftability Theory

Pada tahun 1940-an, sebuah teori perbankan muncul di kalangan perbankan Amerika, yang dikenal dengan nama the shiftability theory (teori tentang aktiva yang dapat dipindahkan). Teori ini menjelaskan bahwa likuiditas suatu bank tergantung pada kemampuan bank tersebut untuk memindahkan aktivanya ke pihak/orang lain dengan harga 


\section{BISMA - Bisnis dan Manajemen -Volume 9 No. 1 Oktober 2016}

yang dapat diramalkan. Jadi, akan dapat diterima bagi sebuah bank untuk menyimpan investasi-investasi pasar erbuka jangka pendek dalam portifolio asetnya. (Veitzhal, 2007: 387) .

Jika dalam keadaan ini sejumlah deposan harus memutuskan untuk menarik kembali uang mereka maka bank hanya tinggal menjual investasi-investasi tersebut, mengambil uang yang diperoleh (dibeli) dan membayarkannya kembali kepada para deposan.

Kelemahan teori ini sama dengan kelemahan teori sebelumnya yaitu apabila pada saat yang sama sistem perbankan membutuhkan likuiditas dan secara serentak menggunakan cara yang sama yaitu menjual sekuritasnya untuk memenuhi kebutuhan likuiditasnya sehingga bankbank dalam waktu yang bersamaan berperan sebagai penjual.

Dalam situasi seperti ini, Bank Sentral biasanya akan melakukan suatu tindakan dengan membeli surat-surat berharga dari semua bank pada saat perbankan meningkatkan likuiditasnya. Di negara negara yang pasar uangnya sudah cukup berkembang dan kegiatan operasi pasar terbuka Bank Sentral sudah berjalan baik, teori ini umumnya cukup efektif digunakan untuk mengatasi kesulitan likuiditas.

\section{The Anticipated Income Theory}

Pada tahun 1930-an sampai 1940-an,bankbankmengembangkan teori baru yang disebut dengan anticipated income theory. Teori ini menjelaskan bahwa setiap bank seharusnya dapat memberikan kredit jangka panjang di mana pelunasannya yaitu cicilan pokok pinjaman ditambah bunga dapat diharapkan dan dijadwalkan pembayarannya pada waktu yang akan datang sesuai dengan jangka waktu yang telah ditetapkan. Jadwal pembayaran kembali nasabah berupa angsuran pokok dan bunga akan memberikan cash flow secara teratur yang dapat digunakan untuk memenuhi kebutuhan likuiditas bank.

Kelemahan anticipated income theory ini yaitu teori ini menganggap bahwa semua kredit dapat ditagih sesuai dengan jangka waktu yang telah dijadwalkan tanpa memperhatikan kemungkinan terjadinya kegagalan pengembalian kredit oleh debitur akibat faktor ekstern atau intern. Faktor-faktor terjadi di luar kendali nasabah misalnya terjadinya resesi ekonomi yang berkepanjangan dan kebijakan pemerintah yang kurang mendukung. Faktor intern antara lain terjadinya mismanagement atau kurangnya tenaga yang berpengalaman dan terampil dalam perusahaan. Teori likuiditas ini sulit diharapkan sebagai sumber likuiditas musiman dan memenuhi kebutuhan permintaan kredit yang harus segera dipenuhi.

\section{The Liability Management Theory.}

Teori ini mengemukakan bagaimana suatu bank dapat menata passivanya sedemikian rupa sehingga passiva ini dapat benar-benar menjadi likuiditas. Kita harus mengetahui mengapa bank memerlukan likuiditas, yakni pertama, untuk melakukan pembayaran atas penarikan dana pihak ketiga (giro, tabungan, dan deposito).

Kedua, bank harus mampu memenuhi semua permintaan pinjaman yang sehat dari nasabahnya. Pinjamanpinjaman dari bank itu tidak hanya menguntungkan, tetapi sebuah bank tidak akan dapat memberikan pinjaman kepada para deposannya bila mereka memerlukan uang, tetapi depositonya tidak disimpan terlalu lama.Manajemen Kualitas Aset

\section{Manajemen Kualitas Aset}

Aset (Kualitas Aset) dinilai berdasarkan kepada kualitas aktiva yang dimiliki bank.Aset (Aktiva) terdiri atas aktiva produktif dan aktiva non produktif. Menurut Peraturan Bank Indonesia aktiva produktif didefenisikan sebagai penyediaan dana Bank untuk memperoleh penghasilan dalam bentuk kredit, surat berharga, penempatan dana antar bank, tagihan akseptasi, tagihan atas surat berharga yang dibeli dengan janji dijual kembali (reverse repurchase agreement), tagihan derivatif,penyertaan, transaksi rekening administratif serta bentuk penyediaan dana lainnya yang dapat dipersamakan dengan itu. (Veitzhal, 2007: 387).

Aset produktif adalah penanaman bank dalam bentuk kredit, surat berharga, penyertaan dan penanaman lainya yang dimaksudkan untuk memperoleh penghasilan. Aktiva non produktif adalah aset Bank selain Aktiva Produktif yang memiliki potensi kerugian, antara lain dalam bentuk agunan yang diambil alih, properti terbengkalai (abandoned property), rekening antar kantor dan suspense account.(menurut Peraturan Bank Indonesia). (Veitzhal, 2007: 387).

\section{Bank Umum}

Undang-Undang RI No.10 Tahun 1998 tentang Perbankan menjelaskan bahwa, "Bank Umum adalah bank yang melaksanakan kegiatan usaha secara konvensional dan atau berdasarkan Prinsip Syariah yang dalam kegiatannya memberikan jasa dalam lalu lintas pembayaran".

\section{Likuiditas (LDR)}

"Likuiditas adalah kemampuan suatu perusahaan dalam memenuhi kewajiban jangka pendeknya" (Hanafi, 2007:76).“Suatu bank dikatakan likuid, apabila bank yang bersangkutan dapat membayar semua hutang-hutangnya terutama simpanan tabungan, giro dan deposito pada saat ditagih dan dapat pula memenuhi semua permohonan kredit yang memang layak untuk dibiayai” (Kasmir, 2013:45). 


\section{Daniel Siahaan dan Nadia Asandimitra-Pengaruh Likuiditas Dan Kualitas Aset...}

Tingkat likuiditas bank salah satunya dapat diukur dengan menggunakan Loan to Deposit Ratio (LDR). Menurut Ismail (2009:191), "Loan to Deposit Ratio (LDR) adalah rasio yang dipergunakan untuk mengukur kemampuan dana pihak ketiga yang dipergunakan untukmemberikan kredit kepada nasabah".

Besarnya loan to deposit ratio (LDR) menurut peraturan pemerintah adalah maksimum $110 \%$. LDR yang rendah menunjukkan tingkat penyaluran kredit yang rendah dibandingkan dana yang diterima, maka dapat diketahui bahwa bank masih jauh dari maksimal dalam melaksanakan fungsi intermediasi. Sesuai dengan Surat Edaran Bank Indonesia No. 13/30/DPNP Tanggal 16 Desember 2011, nilai LDR dapat ditentukan dengan:

\section{Profitabilitas (ROA)}

$$
L D R=\frac{\text { Total Kredit }}{\text { Total Dana Pihak ke Tiga }} \times 100 \%
$$

Analisis profitabilitas digunakan untuk mengukur kemampuan manajemen bank dalam memperoleh keuntungan secara keseluruhan. Rasio profitabilitas dari setiap perusahaan, dapat dihitung dengan beberapa cara yaitu, dengan menggunakan ROA, ROE, NIM, dan ROI.Dalam penelitian ini, pengukuran tingkat profitabilitas dinyatakan dengan Return On Assets (ROA).

Menurut Dendawijaya (2003:120), "Rasio ROA digunakan untuk meng-ukur kemampuan manajemen bank dalam memperoleh keuntungan secara keseluruhan, semakin besar ROA suatu bank semakin besar pula tingkat keuntungan yang dicapai bank tersebut dan semakin baik pula posisi bank tersebut dari segi penggunaan aktiva". Batas minimum yang ditentukan oleh Bank Indonesia adalah 1\%. Jika suatu bank memiliki nilai ROA di atas $1 \%$, maka bank tersebut dapat dikatakan produktif dalam mengelola aktiva sehingga menghasilkan laba dan tergolong dalam kondisi sehat. Penilaian profitabilitas (ROA) dapat ditentukan dengan:

\section{Kualitas aset (NPL)}

$$
\text { ROA } \frac{\text { Net Income }}{\text { Total Assets }} \times 100 \%
$$

Penilaian aset biasanya didasarkan pada penilaian terhadap kualitas aktiva yang dimiliki bank, namun penilaian aset bisa juga didasarkan pada penilaian yang ditinjau dari sudut risiko yang dihadapi bank.Kualitas aset pun berhubungan dengan risiko kredit yang dihadapi bank akibat pemberian kredit.

Kualitas aset adalah perbandingan antara classified assets (kredit kurang lancar, kredit diragukan dan kredit macet) dengan total kredit yang diberikan. Kriteria kredit kurang lancar yaitu kredit yang selama 3 atau 6 bulan mutasinya kurang lancar, pembayaran bunga atau utang pokoknya tidak baik, usaha-usaha approach telah dilakukan tetapi hasilnya tetap kurang baik.

Menurut Taswan (2010:166), "Non Performing Loan merupakan perbandingan antara kredit bermasalah terhadap total kredit". Kredit yang dimaksud disini merupakan kredit yang diberikan kepada pihak ketiga (tidak termasuk kredit kepada bank lain), dan kredit bermasalah adalah kredit dengan kualitas kurang lancar, diragukan dan macet.

Non Performing Loan (NPL) adalah suatu keadaan dimana nasabah sudah tidak sanggup membayar sebagian atau seluruh kewajibannya kepada bank seperti yang telah diperjanjikannya. Sesuai dengan Surat Edaran Bank Indonesia No. 13/30/DPNP Tanggal 16 Desember 2011, nilai NPL dapat ditentukan dengan:

$$
\text { NPL }=\frac{\text { Kredit bermasalah }}{\text { Total kredit yang disalurkan }} \times 100 \%
$$

\section{likuiditas terhadap profitabilitas}

Loan to Deposit Ratio (LDR) merupakan salah satu rasio likuiditas yang sering digunakan dalam menilai kinerja suatu bank, dimana rasio likuiditas merupakan rasio yang menggambarkan kemampuan bank dalam memenuhi kewajiban jangka pendeknya. LDR merupakan rasio antara seluruh jumlah kredit yang diberikan bank dengan dana yang diterima oleh bank dari DPK. Semakin rendah LDR mencerminkan bank tersebut belum mampu mengoptimalkan DPK untuk disalurkan sebagai kredit.Hal ini sesuai dengan teori manajemen likuiditas dengan beberapa teori yang mengikutinya seperti Commercial Loan, Shiftability, The Anticipated Income dan The Liability Management.

Standar yang digunakan Bank Indonesia untuk rasio LDR suatu bank adalah $85 \%$ hingga $110 \%$. Jika angka rasio LDR suatu bank berada pada angka dibawah $85 \%$ (misalkan 70\%), maka dapat disimpulkan bahwa bank tersebut hanya dapat menyalurkan sebesar $70 \%$ dari seluruh dana yang berhasil dihimpun sehingga bank kehilangan kesempatan untuk memperoleh laba. Mtrenurut Nusantara (2009), LDR berpengaruh positif signifikan terhadap ROA. Tetapi pada penelitian Manrov (2009) menyatakan bahwa LDR berpengaruh negative terhadap ROA, dan menurut penelitian Prasnanugraha (2007) bahwa LDR tidak berpengaruh terhadap ROA.

Berdasarkan penjelasan di atas, dapat diprediksi bahwa likuiditas berpengaruh positif terhadap profitabilitas karena semakin banyak dana yang disalurkan sebagai kredit, bank akan menerima bunga kredit yang akan meningkatkan profitabilitas bank, dengan asumsi bahwa bank tersebut 


\section{BISMA - Bisnis dan Manajemen -Volume 9 No. 1 Oktober 2016}

menyalurkan kreditnya secara efektif sehingga tidak terjadi kredit macet.

\section{Kualitas aset terhadap profitabilitas}

Penilaian kualitas aset dihitung dengan rasio Non Performing Loan (NPL). NPL merupakan presentase jumlah kredit yang mengalami kesulitan pengembalian atau kredit bermasalah terhadap total kredit yang disalurkan bank. Kredit yang dimaksud dalam hal ini adalah kredit yang diberikan kepada pihak ketiga, tidak termasuk kredit kepada bank lain. Meningkatnya kredit yang bermasalah akan mengakibatkan kerugian pada bank yang bersangkutan karena tidak diterimanya kembali dana yang telah disalurkan dan bank tersebut juga tidak menerima pendapatan bunga. Tidak diterimanya kembali dana yang telah disalurkan akan mengakibatkan bank harus menyediakan pencadangan yang lebih besar yang akhirnya akan diambil dari modal bank itu sendiri.

Non Performing Loan (NPL) dapat menggambarkan besar atau kecilnya risiko kredit yang akan dihadapi oleh bank. Batas maksimum rasio NPL yang ditetapkan oleh Bank Indonesia adalah 5\%, semakin kecil NPL maka semakin kecil pula risiko kredit yang ditanggung oleh pihak bank. Sebaliknya, jika NPL tinggi maka risiko kredit yang akan ditanggung oleh pihak bank akan semakin besar sehingga kesempatan bank dalam memperoleh laba dari bunga kredit dan pengembalian kredit akan hilang.

Hilangnya kesempatan bank dalam memperoleh laba akan berpengaruh secara langsung terhadap profit yang akan diterima bank yang bersangkutan.Menurut Nusantara (2009), NPL ber-pengaruh negatif signifikan terhadap ROA. Tetapi pada penelitian Prasnanugraha (2007) menyatakan bahwa variabel NPL berpengaruh positif terhadap ROA, dan penelitian Ahmad (2009) bahwa variabel NPL tidak berpengaruh terhadap ROA.

Berdasarkan penjelasan di atas, dapat diprediksi bahwa hubungan kualitas aset dengan profitabilitas berpengaruh negatif signifikan karena semakin banyak kredit bermasalah yang dihadapi bank, maka bunga kredit yang diterima bank akan menurun dan berdampak pada penurunan profitabilitas bank.

\section{Hipotesis}

Berdasarkan rumusan masalah yang telah dikemukakan sebelumnya, maka hipotesisnya adalah:

H1 : Likuiditas berpengaruh terhadap Profitabilitas

H2 : Kua litas aset berpengaruh terhadap Profitabilitas

\section{METODE PENELITIAN}

Penelitian ini menggunakan tiga variabel yang terdiri dari dua variabel bebas yaitu likiuiditas dan kualitas asset, satu variael terikat yaitu profitabilitas.
Likuiditas sebagai variabel bebas yang pertama $\left(\mathrm{X}_{1}\right)$, dalam penelitian ini menggunakan Loan to Deposit Ratio (LDR). LDR merupakan rasio yang dipergunakan untuk mengukur kemampuan dana pihak ketiga yang dipergunakan untuk memberikan kredit kepada nasabah (Ismail, 2009:191).Kualitas aset sebagai variabel bebas yang kedua $\left(\mathrm{X}_{2}\right)$, dalam penelitian ini menggunakan Non Performing Loan (NPL).NPL merupakan perbandingan antara kredit bermasalah terhadap total kredit (Taswan, 2010:166).

Profitabilitas sebagai variabel terikat (Y), dalam penelitian ini menggunakan Return On Assets (ROA). ROA merupakan rasio yang digunakan untuk mengukur kemampuan manajemen bank dalam memperoleh keuntungan (laba) secara keseluruhan (Dendawijaya, 2003:120).

Dalam penelitian sumber data dibagi menjadi dua yaitu data primer dan data sekunder. Data primer adalah data yang diperoleh dari responden melalui kuisioner, kelompok fokus, dan panel atau hasil wawancara peneliti dengan narasumber, sedangkan data sekunder adalah data yang berupa seperti catatan atau dokumentasi perusahaan berupa absensi, gaji, laporan keuangan publikasi perusahaan, laporan pemerintah dan lain sebagainya.

Sumber data yang digunakan dalam penelitian ini merupakan sumber data sekunder yang berupa laporan keuangan Bank Umum Nasional yang terdaftar di Bursa Efek Indonesia periode 2010-2014.Sumber data yang digunakan diperoleh dari website Bank Indonesia dan website Bursa Efek Indonesia.

Populasi yang akan digunakan dalam penelitian ini adalah Bank Umum Nasional yang terdaftar di Bursa Efek Indonesia. Sampel yang digunakan dalam penelitian ini diperoleh dengan meggunakan metode purposive sampling, yaitu metode pengambilan sampel berdasarkan kriteriakriteria tertentu sebagai berikut:

1. Bank tersebut merupakan bank yang terdaftardi Bursa Efek Indonesia selama periode 2010 sampai dengan 2014.

2. Laporan keuangan bank yang akan dijadikan sampel tersedia berturut-turut untuk tahun pelaporan dari 2010 sampai dengan 2014 dalam mata uang rupiah.

3. Bank mempublikasikan laporan keuangan yang diaudit dengan menggunakan tahun buku yang berakhir pada tanggal 31 Desember.

4. Bank tersebut tidak mengalami kerugian dalam laporan laba/rugi bersih selama periode 2010 sampai dengan 2014.

Teknik analisis yang digunakan dalam penelitian ini merupakan pendekatan kuantitatif dengan menggunakan alat 


\section{Daniel Siahaan dan Nadia Asandimitra-Pengaruh Likuiditas Dan Kualitas Aset...}

statistik deskriptif dan pengujian hipotesis. Statistik deskriptif digunakan untuk memberikan deskripsi mengenai variabel-variabel penelitian yang terdiri dari likuiditas (LDR), kualitas aset (NPL), dan profitabilitas (ROA).

1. Menghitung Likuiditas (LDR) dengan rumus:

$$
L D R=\frac{\text { Total Kredit }}{\text { Total Dana Pihak ke Tiga }} \times 100 \%
$$

2. Menghitung Kualitas Aset (NPL) dengan rumus:

$$
N P L=\frac{\text { Kredit bermasalah }}{\text { Total kredit yang disalurkan }} x 100 \%
$$

3. Menghitung Profitabilitas (ROA) dengan rumus:

$$
\text { ROA } \frac{\text { Net Income }}{\text { Total Assets }} \times 100 \%
$$

\section{Melakukan pengujian terhadap asumsi klasik}

Penggunaan analisis regresi linear berganda memerlukan uji asumsi klasik atau uji persyaratan analisis regresi linear berganda sehingga persamaan garis regresi yang diperoleh benar-benar dapat digunakan untuk memprediksi variabel dependen. Uji persyaratan tersebut harus terpenuhi, apabila tidak maka akan menghasilkan garis regresi yang tidak cocok untuk memprediksi (Sudarmanto:2005).

\section{Uji Linearitas}

Uji Linearitas digunakan untuk menguji linear tidaknya suatu data yang dianalisis yaitu variabel independent terhadap variabel dependen.Pada penelitian ini, uji linearitasnya dilakukan dengan melihat signifikansi linearity pada tabel Anova.

Jika signifikansi $<0,05$ maka dapat disimpulkan bahwa data tersebut dinyatakan memilikki hubungan linear antar variabel.

\section{Uji Normalitas}

Uji normalitas bertujuan untuk menguji apakah dalam model regresi, variabel pengganggu atau residual mempunyai distribusi normal. Uji normalitas atas residual ini penting karena uji $\mathrm{t}$ dan uji $\mathrm{F}$ mengasumsikan bahwa nilai residual memiliki distribusi normal. Asumsi ini jika dilanggar maka uji statistik menjadi tidak valid.

Uji normalitas dapat dilakukan dengan melihat grafik plot. Jika data menyebar disekitar garis diagonal dan

mengikuti arah garis tersebut maka itu menunjukkan pola distribusi normal. Kemudian bisa dilihat juga melalui grafik histogram. Jika grafik histogram tidak menceng atau seimbang maka dapat dikatakan data normal.

Selain itu melalui uji Kolmogorov-Smirnov dengan bantuan SPSS. Jika signifikansi di bawah 0,05 mengartikan bahwa terdapat perbedaan yang dignifikan dengan data normal baku sehingga data tersebut tidak normal. Jika signifikansi di atas 0,05 mengartikan bahwa tidak terdapat perbedaan yang signifikan antara data uji dengan data normal baku sehingga data tersebut berdistribusi normal

\section{Uji Multikolinearitas}

Gejala multikolinearitas terjadi jika terdapat korelasi yang kuat antara variabel-variabel bebas. Sehingga akan menimbulkan konsekuensi yaitu nilai koefisien regresi variabel-variabel bebas memiliki standar deviasi yang besar, maka kemungkinan besar menjadi tidak signifikan secara statistik. Mendeteksi gejala multikolinearitas dapat dilihat dari nilai VIF (Variance Inflation Factor) pada hasil output SPSS.Batasan nilai yang umum dipakai untuk menunjukkan adanya multikolinearitas adalah VIF > 10 dan tolerance < 0,1 . Jika nilai $\mathrm{VIF}<10$ dan tolerance value $>0,1$ maka dapat disimpulkan bahwa tidak terjadi multikolinearitas antar variabel independen dalam suatu model regresi.

\section{Uji Autokorelasi}

Gejala autokorelasi terjadi karena terdapat korelasi antara variabel pengganggu pada periode $t$ dengan variabel pengganggu pada periode t-1. Jika terjadi korelasi maka dinamakan terjadi masalah autokorelasi (Ghozali, 2009). Model regresi yang mengalami gejala autokorelasi memiliki standar error yang sangat besar, sehingga menjadi tidak signifikan. Pengujian adanya autokorelasi dalam model persamaan regresi adalah menggunakan uji Durbin-Watson (D-W Test). Menurut Ghozali (2009) dasar pengambilan keputusan adalah:

Tabel 3.1 Pengambilan Keputusan Autokorelasi

\begin{tabular}{|l|l|l|}
\hline \multicolumn{1}{|c|}{ Hipotesis Nol } & Keputusan & \multicolumn{1}{c|}{ Jika } \\
\hline $\begin{array}{l}\text { Tidak ada } \\
\text { autokorelasi positif }\end{array}$ & Tolak & $0<\mathrm{DW}<\mathrm{dl}$ \\
\hline $\begin{array}{l}\text { Tidak ada } \\
\text { autokorelasi positif }\end{array}$ & No decision & $\mathrm{dL} \leq \mathrm{DW} \leq \mathrm{dU}$ \\
\hline $\begin{array}{l}\text { Tidak ada korelasi } \\
\text { negative }\end{array}$ & Tolak & $4-\mathrm{dL}<\mathrm{DW}<4$ \\
\hline Tidak ada korelasi & No & $4-\mathrm{dU} \leq \mathrm{DW} \leq 4$ \\
\hline
\end{tabular}


BISMA - Bisnis dan Manajemen -Volume 9 No. 1 Oktober 2016

\begin{tabular}{|l|l|l|} 
negative & decision & $-\mathrm{dL}$ \\
\hline $\begin{array}{l}\text { Tidak ada } \\
\text { autokorelasipositif } \\
\text { atau negative }\end{array}$ & $\begin{array}{l}\text { Tidak } \\
\text { ditolak }\end{array}$ & $\mathrm{dU}<\mathrm{DW}<4-$ \\
\hline
\end{tabular}

\section{Heteroskedastisitas}

Menurut Imam Ghozali (2013:139) ujiheteroskedatisitas bertujuan menguji apakah dalam model regresi terjadi ketidaksamaan varians dari residual satu pengamatan ke pegamatan lain. Jika varians dari residual satu pengamatan kepengamatan lain tetap, maka di sebut homokedastisitas dan jika berbeda disebut heteros kedastisitas. Cara menguji ada tidaknya heteroskedastisitas, yaitu dengan menggunakan analisis grafik scatterplot. Pengujian scatterplot model regresi yang tidak terjadi heteroskedastisitas harus memeuhi syarat sebagai berikut:

a. Jika ada pola tertentu, seperti titik-titik yang ada membentuk pola tertetu yang teratur (bergelombang, melebar kemudian menyempit), maka mengindikasikan telah terjadi heteroskedastisitas.

b. Jika tidak ada pola yang jelas serta titik-titik menyebar diatas dan dibawah angka 0 pada sumbu Y, maka tidak terjadi heteroskedastisitas.

Uji Heteroskedastisitas dapat juga dilakukan dengan uji Glejser yang bertujuan untuk menguji apakah dalam model regresi terjadi ketidaksamaan variancedari residual satu pengamatan ke pengamatan yang lain. Model regresi yang baik maka tidak terjadi Heteroskedastisitas. Tingkat signifikasi yang digunakan dalam uji ini adalah nilai signifikansi $>0,05$.

\section{Pengujian Hipotesis dengan Model Linier}

a. $\quad$ ji $R^{2}$ (Koefisien Determinasi)

Nilai $R^{2}$ memiliki interval 0 hingga 1 . Semakin besar $R^{2}$ (mendekati 1), maka semakin baik hasil untukmodel regresi tersebut. Tetapi jika $\mathrm{R}^{2}$ mendekati 0 , maka variabel independen secara keseluruhan tidak dapat menjelaskan variabel dependen. Kelemahan penggunaan koefisien determinasi adalah bias terhadap jumlah variabel independen yang dimasukkan kedalam model

Setiap tambahan satu variabel independen maka akan menyebabkan $\mathrm{R}^{2}$ pasti meningkat tidak perduli apakah variabel tersebut berpengaruh secara signifikan terhadap variabel dependen. Sehingga banyak peneliti menganjurkan untuk menggunakan nilai Adjusted $\mathrm{R}^{2}$ pada saat mengevaluasi mana model regresi terbaik (Ghozali, 2009). Penelitian ini menggunakan Adjusted $\mathrm{R}^{2}$ dalam mengukur seberapa jauh kemampuan model dalam menerangkan variasi variabel dependen.

b. Uji F

Uji $F$ dilakukan untuk melihat pengaruh variabelvariabel independen secara keseluruhan terhadap variable dependen (Sulaiman, 2004). Uji ini dilakukan dengan membandingkan nilai signifikansi (tingkat keyakinan) $\mathrm{F}$ dengan tingkat signifikansi. Tingkat signifikansi yang digunakan dalam penelitian ini adalah 0,05. Jika signifikansi $\mathrm{F}<0,05$, maka secara keseluruhan variabel independen dapat menjadi penjelas yang signifikan bagi variabel dependen (Ghozali:2009). Jika signifikansi F > tingkat signifikansi, maka secara keseluruhan variabel independen tidak dapat menjadi penjelas yang signifikan bagi variabel dependen.

c. Uji t

Uji t menunjukkan seberapa jauh satu variabel penjelas (independen) secara individual dalam menerangkan variasi variabel independen. Uji ini dilakukan dengan membandingkan nilai signifikansi $\mathrm{t}$ dengan tingkat signifikansi (tingkat keyakinan) yang digunakan dalam penelitian ini. Tingkat signifikansi yang digunakan dalam penelitian ini adalah 0,05 . Jika signifikansi $\mathrm{t}<0,05$ maka secara individu satu variabel independen berpengaruh terhadap variabel dependen. Jika signifikansi t $>0,05$ maka secara individual satu variabel independen tidak berpengaruh terhadap variabel dependen.

\section{HASIL DAN PEMBAHASAN}

Uji Linearitas digunakan untuk menguji linear tidaknya suatu data yang dianalisis yaitu variabel independent terhadap variabel dependen dengan nilai signifikansi $<0,05$ pada tabel anova.

Tabel 4.7 Uji Linearitas

\begin{tabular}{|c|c|}
\hline Variabel & Sig. \\
\hline ROA-LDR &, 048 \\
\hline ROA-NPL &, 027 \\
\hline
\end{tabular}




\section{Daniel Siahaan dan Nadia Asandimitra-Pengaruh Likuiditas Dan Kualitas Aset...}

hasil uji linearitas pada tabel diatas dapat diketahui bahwasemua variabel memiliki nilai signifikansi $<0,05$, hal ini menunjukkan bahwa semua variabel penelitian adalah linear.

Uji normalitas bertujuan untuk menguji apakah dalam model regresi, variabel terikat dan variabel bebas keduanya

Tabel 4.8 One-Sample Kolmogorov-Smirnov Test

\begin{tabular}{|l|l|}
\hline & \multicolumn{1}{|c|}{ Unstandardized Residual } \\
\hline Kolmogorov- Smirnov Z & 1,308 \\
\hline Asymp. Sig. (2- tailed) & 065 \\
\hline
\end{tabular}

Menurut Ghozali (2011:105) uji multikolonieritas bertujuan untuk menguji apakah model regresi ditemukan adanya korelasi antar variabel bebas (independen). Model regresi yang baik seharusnya tidak terjadi korelasi di antara variabel independen.Untuk mendeteksi ada atau tidaknya multikolinearitas yang tinggi antar variabel independen dapat dideteksi dengan cara melihat nilai tolerance dan mempunyai distribusi normal atau tidak. Model regresi yang baik adalah memiliki distribusi data normal atau mendekati normal.

\section{Tabel 4.9 Hasil Uji Multikolinieritas}

\begin{tabular}{|l|l|l|}
\hline Variabel Independen & Tolerance & VIF \\
\hline LDR & 0,967 & 1,034 \\
\hline NPL & 0,967 & 1,034 \\
\hline
\end{tabular}

Hasil uji multikolinearitas pada tabel 4.6 menunjukkan bahwa hasil perhitungan nilai tolerance dari keempat variabel independen tidak ada yang memiliki nilai kurang dari 0.1.Sedangkan hasil perhitungan nilai Variance Inflation Factor(VIF)juga menunjukkan hal yang sama, tidak ada satupun variabel independen yang memiliki nilai VIF lebihdari 10. Dengan demikian dapat disimpulkan bahwa dalam model regresi tersebut tidak terdapat masalah multikolinieritas, maka model regresi yang ada layak untuk dipakai.

Tabel 4.10Hasil Durbin-Watson (DW test)

\begin{tabular}{|l|l|l|}
\hline $\mathrm{Du}$ & Durbin - Watson & 4-du \\
\hline 1,7688 & 1,908 & 2,2332 \\
\hline
\end{tabular}

Berdasarkan tabel 4.10 menunjukkan nilai DurbinWatson sebesar 1,908. Jika dibandingkan dengan tabel Durbin-Watson dengan jumlah observasi $(n)=160$ dan jumlah variabel independen $(\mathrm{k})=2$, karena nilai $\mathrm{DW}$

\section{e. Uji Heteroskedastisitas}

variance inflation factor (VIF). Nilai cutoff yang umum dipakai untuk menunjukkan tidak terjadi multikolinearitas adalah nilai tolerance di atas 0,1 atau sama dengan nilai VIF di bawah

Hasil uji multikolinearitas dapat dilihat pada Tabel 4.9 berikut:

Uji Autokorelasi bertujuan untuk menguji adanya korelasi antara kesalahan penganggu pada periode $t$ dengan kesalah penganggu pada periode t-1 (sebelumnya) dalam model regresi linier. Dalam penelitian ini uji autokorelasi dilakukan dengan menggunakan uji Durbin-Watson (DWtest) dan uji run test. Apabila nilai durbin-watson memenuhi persamaan $\mathrm{du}<\mathrm{d}<4-$ du maka tidak terdeteksi autokorelasi. Berikut adalah hasil uji Durbin-Watson yang dapat dilihat dari tabel 4.10 berikut:

1,908lebih besar dari batas $(\mathrm{du})=1.7668$ dan kurang dari 4 du $(4-1,7668)=2,2332$. Maka dapat disimpulkan bahwa tidak terdapat autokorelasi baik positif maupun negatif

Tabel 4.11 Hasil uji Glejser

\begin{tabular}{|l|l|}
\hline Model & Sig. \\
\hline \multicolumn{1}{|c|}{ (Constant) } & .408 \\
\hline 1LDR & .795 \\
\hline
\end{tabular}


BISMA - Bisnis dan Manajemen -Volume 9 No. 1 Oktober 2016

NPL

Berdasarkan tabel 4.10 menunjukkan bahwa nilai signifikansi untuk masing-masing variabel independen pada persamaan model regresi terhadap nilai absolut residualnya $>0,05$. Dengan demikian dapat disimpulkan bahwa data tersebut tidak terjadi heteroskedastisitas.

Langkah selanjutnya adalah untuk mengetahui pengaruh antara variabel bebas (motivasi kerja) dan variabel intervening (kepuasan kerja) dengan variabel terikat (kinerja karyawan) baik secara parsial maupun secara simultan dengan melihat tabel uji $\mathrm{t}$ dan uji $\mathrm{F}$ pada tabel 1 mengenai koefisien model persamaan regresi dan tabel 2 mengenai hasil uji ANOVA.

Tabel 1. Koefisien model persamaan regresi.

\section{Coefficients $^{\mathrm{a}}$}

\begin{tabular}{lllll}
\hline Unstandardized & $\begin{array}{l}\text { Standardiz } \\
\text { ed }\end{array}$ & & \\
Coefficients & Coefficien & & & Sig.
\end{tabular}

Model

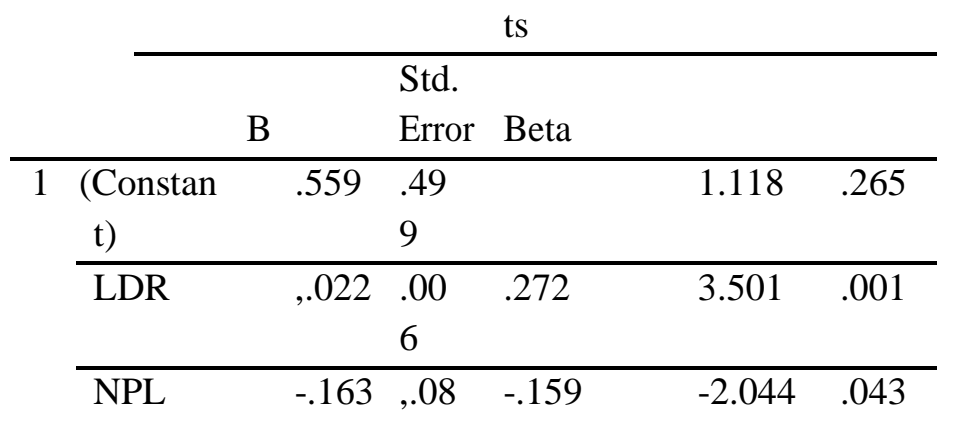

0
a.Dependent Variable: Profitabiltas

Berdasarkan tabel 1 tersebut, terlihat pada angka signifikansi atau besaran nilai probabilitas dari variabel LDR angka signifikansi 0,001 dan angka signifikansi NPL 0,043 berada dibawah 0,005. Hal tersebut menunjukkan bahwa terdapat pengaruh LDR dan NPL terhadap Profitabilitas.

Tabel 2. Hasil uji ANOVA atau F test

\begin{tabular}{|c|c|c|c|c|c|}
\hline \multicolumn{6}{|c|}{ ANOVA $^{b}$} \\
\hline \multirow[t]{2}{*}{ Model } & Sum of & & Mean & & \\
\hline & Squares & Df & Square & $\mathrm{F}$ & Sig. \\
\hline 1 Regression & 18.266 & 2 & 9.133 & 7,159 & ,001 \\
\hline Residual & 200.283 & 157 & 1,276 & & \\
\hline Total & 218.549 & 159 & & & \\
\hline
\end{tabular}

a. Predictors: (Constant), LDR, NPL

b. Dependent Variable: Profitabilitas

Berdasarkan tabel 2 tersebut, nilai signifikansi menunjukkan nilai praktis 0,001 yang menunjukkan bahwa LDR dan NPL berpengaruh secara simultan terhadap
Profitabilitas. Setelah mengetahui pengaruh secara parsial dan simultan, perlu diketahui juga mengenai seberapa besar pengaruh LDR dan NPL terhadap Profitabilitas yang tersaji pada tabel 3 berikut.

Tabel 3.Persentase besar hubungan variabel bebas terhadap variabel terikat

\section{Model Summary ${ }^{b}$}

\begin{tabular}{|c|c|c|c|c|}
\hline \multirow{2}{*}{ Model } & \multirow{2}{*}{$\mathrm{R}$} & $\mathrm{R}$ & Adjusted & Std. Error of the \\
\hline & & Square & R Square & Estimate \\
\hline$\overline{1}$ &, 289 & $\overline{, 084}$ &, 072 & 1,1259 \\
\hline
\end{tabular}




\section{Daniel Siahaan dan Nadia Asandimitra-Pengaruh Likuiditas Dan Kualitas Aset...}

Berdasarkan tabel 3 tersebut, nilai $\mathrm{R}$ Square menunjukkan angka 0,084 atau $8,4 \%$ dalam persentase. Hal ini menunjukkan bahwa LDR dan NPL dapat menjelaskan hasil dari keterhubungannya dengan Profitbilitas berdasarkan persentase yang didapatkan yaitu sebesar $8,4 \%$, sementara $92,6 \%$ sisanya dijelaskan oleh sebab-sebab lain yang tidak diteliti.

\section{Pengaruh LDR dan NPL terhadap Profitabilitas}

Penelitian ini bertujuan untuk mengetahui pengaruh Likuiditas (LDR) dan Kualitas aset (NPL) terhadap Profitabilitas (ROA) pada bank umum nasional di Bursa Efek Indonesia periode 2010-2014. Dengan menggunakan analisis regresi linier berganda, maka penelitian ini berhasil menemukan bahwa:

Likuiditas berpengaruh terhadap ROA. Hal ini berarti Likuiditas sangat berkaitan erat dengan dana yang dimiliki oleh bank, maka suatu bank harus dapat menjaga likuiditasnya agar berada pada tingkat yang optimal. Dalam upaya untuk memenuhi kewajiban jangka pendeknya, bank harus dapat menyediakan sumber-sumber pembayaran yang dapat segera direalisasikan. Oleh sebab itu bank dikatakan likuid apabila mempunyai alat pembayaran untuk memenuhi kewajiban yang jatuh tempo. Jika suatu bank tidak likuid, maka kewajiban jangka pendeknya yang jatuh tempo tidak dapat dilunasi karena kurang tersedianya sumber daya finansial. Hal ini dapat menyebabkan krisis keuangan dan menurunnya tingkat kesehatan pada bank.

Kualitas aset berpengaruh negatif terhadap profitabilitas. Hal ini menunjukkan apabila NPL pada suatu bank tersebut tinggi (diatas 5\%) berarti bank tersebut dinyatakan tidak sehat. NPL yang tinggi menyebabkan menurunnya laba yang akan diterima oleh bank

\section{KESIMPULAN}

Penelitian ini bertujuan untuk mengetahui pengaruh Likuiditas (LDR) dan Kualitas aset (NPL) terhadap Profitabilitas (ROA) pada bank umum nasional di Bursa Efek Indonesia periode 2010-2014. Dengan menggunakan analisis regresi linier berganda, maka penelitian ini berhasil menemukan bahwa:

1. Likuiditas berpengaruh terhadap ROA. Hal ini berarti Likuiditas sangat berkaitan erat dengan dana yang dimiliki oleh bank, maka suatu bank harus dapat menjaga likuiditasnya agar berada pada tingkat yang optimal. Dalam upaya untuk memenuhi kewajiban jangka pendeknya, bank harus dapat menyediakan sumber-sumber pembayaran yang dapat segera direalisasikan. Oleh sebab itu bank dikatakan likuid apabila mempunyai alat pembayaran untuk memenuhi kewajiban yang jatuh tempo. Jika suatu bank tidak likuid, maka kewajiban jangka pendeknya yang jatuh tempo tidak dapat dilunasi karena kurang tersedianya sumber daya finansial. Hal ini dapat menyebabkan krisis keuangan dan menurunnya tingkat kesehatan pada bank.

2. Kualitas aset berpengaruh negative terhadap profitabilitas. Hal ini menunjukkan apabila NPL padasuatu bank tersebut tinggi (diatas 5\%) berarti bank tersebut dinyatakan tidak sehat. NPL yang tinggi menyebabkan menurunnya laba yang akan diterima oleh bank keuangan dan perbankan serta sebagai bahan referensi untuk penelitian selanjutnya.

\section{SARAN}

Saran yang dapat diberikan berdasarkan hasil penelitian dan pembahasan pada bab sebelumnya yang diharapkan dapat memberikan manfaat bagi pihak-pihak yang berkepentingan dengan penelitian ini adalah sebagai berikut:

1. Bagi Bank

Hasil penelitian ini diharapkan dapat digunakan sebagai bahan pertimbangan dalam mengambil tindakan untuk meningkatkan profitabilitas bank dengan memperhatikan likuiditas dan kualitas aset sehingga dapat menjamin kelangsungan hidup bank tersebut.

2. Bagi Nasabah

Diharapkan dapat membantu nasabah dalam menilai tingkat kesehatan bank dan dapat mengetahui bagaimana kondisi perbankan di Indonesia.

3. Bagi Peneliti Selanjutnya

a. Peneliti selanjutnya sebaiknya melakukan penelitian serupa dengan menambahkan variabel atau dengan menggunakan variabel yang berbeda, periode yang berbeda, dengan jumlah sampel yang lebih banyak sehingga mampu memperkuat hasil penelitianpenelitian yang telah dilakukan sebelumnya.

b. Penelitian ini diharapkan dapat menjadi sumber informasi untuk menambah pengetahuan dalam bidang

\section{REFERENSI}

Agus, Susi Surya (2011). Analisis Pertumbuhan Modal dan Asset Terhadap Rasio Risk Based Capital (RBC) Perusahaan Asuransi Umum di Indonesia. Pekbis Jurnal, Vol.3 No.1, Maret 2011: 391-405

Almilia, Luciana Spica dan Winny Herdiningtyas. 2005. Analisis Rasio CAMELterhadap prediksi kondisi 


\section{BISMA - Bisnis dan Manajemen -Volume 9 No. 1 Oktober 2016}

Bermasalah Pada Lembaga Perbankan Periode 20002002. Jurnal Akuntansi dan Keuangan.

Bank Indonesia. 2004. Peraturan Bank Indonesia No.6/23/DPNP Tanggal 31 mei 2004 tentang Sistem Penilaian Tingkat Kesehatan Bank Umum.

Buyung, Ahmad. 2009. Analisis Pengaruh NPL, CAR, LDR, dan BOPO Terhadap Profitabilitas Bank (Perbandingan Bank Umum Go Publik dan Bank Umum Non Go Publik di Indonesia Periode Tahun 2005-2007) Tesis Program Pascasarjana Magister Manajemen UNDIP.

Curtis, Victor and Samuel Antwi. 2013. The Relationship Between Liquidity and Profitability of Listed Banks In Ghana. Koforidua Polytechnic, Ghana. Jurnal

Dendawijaya, Lukman. 2003. Manajemen Perbankan. Jakarta: PT. Galia.

Downes, John \& J.E.Goodman. 2000. "Kamus Istilah Keuangan dan Investasi", Budisantoso, Totok. Akuntansi Manajerial, Salemba Empat. Jakarta.

Febrianty. 2013. Pengaruh Ukuran Perusahaan, Kecukupan

Modal, Kualitas Aktiva Produktif (KAP), dan Likuiditas terhadap Kinerja Keuangan (Studi Pada Bank Umum Nasional Yang Terdaftar di BEI periode 20082011). Jurnal Ekonomi dan Informasi Akuntasi (JENIUS).

Fred, J dan Thomas E. Copeland. 2001. Manajemen Keuangan, Penerbit Bina Rupa Aksara, Jakarta.

Galih, Tito Adhitya dan Wahyu Meranto. 2011. Pengaruh Dana Pihak Ketiga, Capital Adequacy Ratio, Non Performing Loan, Return On Assets, dan Loan to Deposit Ratio terhadap jumlah penyaluran kredit. Jurnal

Ghozali, Imam. 2009. Aplikasi Analisis Multivariate dengan Program SPSS. Cetakan IV. Semarang: Badan Penertiban UNDIP.

Gorrison Norren, 2000. "Managerial Accounting", yang dialih bahasakan oleh Budisantoso, Totok, Salemba Empat, Jakarta.

Husein, Umar. 2000. Riset Pemasaran Dan Perilaku Konsumen, Jakarta: PT Gramedia Pustaka.

Ismail. 2009. Akuntansi Bank: Teori dan Aplikasi dalam Rupiah, Jakarta: Kencana Prenada Media.

Kasmir. 2002. Manajemen Perbankan, Jakarta:PT. Raja Grafindo Persada.

Kasmir.2008. Bank dan Lembaga Keuangan Lainnya. Edisirevisi. Jakarta: PT. Raja Grafindo Persada. Kieso, Donald E, et.al, 2002. Akuntansi Intermediate, (diterjemahkan oleh Herman Wibowo), Edisi Kesepuluh, Penerbit Erlangga, Jakarta.
Kuntjoro, Mudjarad. 2002. Metode Penelitian Teori dan Aplikasi Untuk Bisnis dan Ekonomi, Ed Pertama. Yogyakarta: UPP-AMP YKPN.

Lestari, Tika. 2010. Pengaruh Rasio Camel Terhadap Kinerja Keuangan Perbankan yang terdaftar di BEI. Medan Fakultas Ekonomi Universitas Sumatera Utara.

Malhotra, Naresh K. 2009. Riset Pemasaran Pendekatan Terapan Jilid 1. Jakarta: PT Index.

Mamduh M.Hanafi dan Abdul Halim, 2003. Analisa Laporan Keuangan, UPP, AMP, YPKM, Yogyakarta.

Manrov, Nainggolan, 2009, Analisis Pengaruh LDR, NIM, dan BOPO terhadap ROA, Skripsi program sarjana Fakultas Ekonomi Universitas Sumatera Utara.

Mudrajad Kuncoro, 2001. Metode Kuantitatif Teori dan Aplikasi Untuk Bisnis dan Ekonomi, Edisi Pertama, UPP AMP YPKN. Yogyakarta.

Munandar, M. 1996. Pokok-Pokok Intermediate Accounting, Edisi Keenam, Penerbit Gajah Mada University, Yogyakarta.

Nazir, M. 1999. Metode Penelitian, Cetakan Keempat, Penerbit Ghalia Indonesia, Jakarta.

Nopirin, PHD. !990. Ekonomi Moneter. Buku Satu. Edisi Ketiga. Yogyakarta: BPFE- UGM. Perbankan, Edisi 3, BPFE Yogyakarta.

Prasnanugraha P, Ponttie, 2007, Analisis Pengaruh Rasio- rasio Keuangan Terhadap Kinerja Bank Umum di Indonesia (Studi Empiris Bank-bank umum yang beroperasi di Indonesia). Program Studi Magister Sains Akuntansi Program Pascasarjana UNDIP. Tesis

Prastowo, Dwi dan Rifka Juliaty, 2002. Analisis Laporan Keuangan, Cetakan Kedua, Penerbit AMP YKPN, Yogyakarta.

Puspitasari Diana, 2009, Analisis Pengaruh CAR, NPL, PDN, NIM, BOPO, LDR, dan Suku Bunga SBI Terhadap ROA (Studi Pada Bank Devisa di Indonesia Periode 2003-2007), Tesis Program Pascasarjana Magister Manajemen UNDIP Semarang.

Rindi Antika, 2004. Tinjauan Atas Analisis Laporan Arus Kas Pada PT Sucofindo (Persero) Bandung, STIE INABA.

Riyanto, Bambang. 1998. Dasar-Dasar Pembelanjaan Perusahaan, Yayasan Badan Penerbit Gajah Mada, Yogyakarta.

Rosdiana, Nana. 2012. Analisis Pengaruh CAR, LDR, NIM, NPL, BOPO, dan DPK terhadap Kinerja Keuangan Perbankan (Studi Kasus Pada Bank Umum yang terdaftar di BEI Periode 2008-2011). Skripsi Fakultas Ekonomi dan Bisnis UNDIP Semarang. 


\section{Daniel Siahaan dan Nadia Asandimitra-Pengaruh Likuiditas Dan Kualitas Aset...}

Sarwono, Jonathan. 2005. SPSS Teori dan Latihan, Edisis II, Penerbit Danamartha Sejahtera Utama, Bandung

Sofyan Syafri Harahap, 2001. Analisis Kritis Atas Laporan Keuangan, Edisi revisi, PT Raja Grafindo Persada. Jakarta.

Simamora, Henry. 2000. Akuntansi: Basis Pengambilan Keputusan Bisnis, Cet I Jilid 2, , Penerbit : Salemba Empat. Jakarta.

Suad, Husnan dan Enny Pudjiastuti. 1998. Dasar-Dasar Manajemen Keuangan, Edisi Kedua, Penerbit : Akademi Manajemen Perusahaan YKPN. Yogyakarta. Sugiyono, 2004. Metode Penelitian Bisnis, Cetakan Ketujuh, Penerbit Alfabeta, Bandung.

S. Munawir, 2002. Analisa Laporan Keuangan, Cetakan Ketiga, Penerbit PT Raja Grafindo Persada, Jakarta.
Syamsudin, Lukman. 2002. "Manajemen Keuangan Perusahaan", Edisi Baru. PT. Raja Grafindo Persada. Jakarta.

Taswan dan Hersugondo, 1997. Analisis Pengaruh CAR, NPL, ROA, dan BOPO terhadap LDR (Studi Kasus pada Bank Umum Swasta Nasional Devisa di Indonesia Periode 2005-2008).

Widheya, I Putu Jias. 2011. Pengaruh Non Performing Loan (NPL, Capital Adequacy Ratio (CAR), dan Loan to Deposit Ratio (LDR) Terhadap Tingkat Profitabilitas melalui Jumlah Kredit Yang Disalurkan (Studi Pada Perusahaan Perbankan Yang terdaftar di BEI Periode 2005-2009). Skripsi ini tidak diterbitkan. Surabaya Fakultas Ekonomi dan Bisnis Universitas Airlangga. 